\title{
KARAKTERISTIK POINT BAR DI SUNGAI BOGOWONTO, KABUPATEN PURWOREJO, PROVINSI JAWA TENGAH
}

\author{
Oleh: \\ Suprapto Dibyosaputro \\ Departemen Geografi Lingkungan Fakultas Geografi Universitas Gadjah Mada \\ Supraptod@ugm.ac.id
}

\begin{abstract}
Abstrak
Point bar merupakan bentukan khas dari sebuah proses fluvial yang perubahan atau dinamikanya dapat berlangsung lambat atau sangat cepat sebagai respon dari proses yang terjadi pada DAS di mana point bar terbentukkan dan karakteristik aliran pada sungai. Dinamika yang terjadi padanya dapat menyebabkan bertambahnya lahan yang dapat dimanfaatkan oleh manusia, namun di sisi yang lain dapat menyebabkan kerusakan lahan pada sisi lain dari sungai. Penelitian ini bertujuan untuk mengetahui karakteristik point bar yang terbentuk di Sungai Bogowonto Kabupaten Purworejo Jawa Tengah. Analisis karakteristik point bar dilakukan dengan pengamatan multi temporal citra resolusi tinggi dan foto udara hasil pemotretan dengan pesawat tanpa awak, serta survei lapangan. Hasil penelitian menunjukkan bahwa point bar selalu berkembang sejalan dengan berkembangnya sungai menjadi meander dan terus berkembang semakin luas pada lengkung dalam meander sungai dengan membentuk igir dan lembah yang series.
\end{abstract}

Kata kunci: Karakteristik, Point Bar, Sungai Bogowonto

\section{Abstract}

Point bar is a typical formation of fluvial processes in which its change or dynamics may be slow or very fast as a response to the processes that occur in the watershed where point bar is formed and the characteristics of the river flow. The dynamics of point bar may lead to the increased land that can be utilized by humans, on the other hand it can cause damage to the land on the other sides of the river. This research aims to know the characteristics of the point bar formed in Bogowonto River, Purworejo regency, Central Java. The analysis of point bar characteristics was performed using a high resolution multitemporal imagery and aerial photos captured by drone, and a field survey. The findings show that point bar is always evolving in line with the development of river meanders and continues to spread more widely in the inner bend of the river meanders by forming a ridge and a series of valley.

Keywords: Characteristic, Point Bar, Bogowonto River

\section{PENDAHULUAN}

Morfologi sungai secara planar pada awalnya mempunyai bentuk yang lurus. Berubahnya posisi tali arus (thalweg) yang tidak selalu di tengah alur sungai menjadikan dinding tebing sungai yang terkena hantaman (impact) tali arus terkikis/tererosi ke arah lateral. Disaat sungai mengangut sedimen dalam jumlah besar, aliran sungai mempunyai kekentalaan (stream viscosity) tingggi dan menyebabkan permukaan aliran sungai menjadi 
miring, sehingga aliran sungai menjadi lebih deras. Derasnya aliran tersebut menjadikan arah aliran arus sungai tak beraturan, ada yang arahnya kesamping akibatnya menumbuk dan mengerosi dinding tebing sungai. Alur menjadikan menjadi lebih lebar dan bersamaan pula membentuk alur yang melengkung (sinous). Penyebab lain berpindahnya tali arus sungaiu ini dapat terjadi karena adanya penghalang aliran air sungai berupa endapan sedimen di dalam alur sungai atau batuan besar pada dasar sungai menjadi penghalang aliran air sungai. Dengan demikian aliran air sungai berbelok ke samping dan mengikis dinding tebing sungai yang terkena hantaman tali arus sungai dan akkhirnya tebing sungai tergerus dan tererosi kesamping oleh aliran air sungai tersebut.

Bagian dinding yang tergerus oleh hantaman tali arus, alur menjadi lebih lebar dan membentuk kelokan yang cembung mendatar, arah keluar badan sungai menjadi bagian lengkung luar. Lama kelamaan sungai melengkung dan arus yang mengalir serta menghantam kelokan sungai, tali arus dipantulkan oleh dinding tebing sungai tersebut dan mengalir ke arah sisi seberang dinding depan tebing sungai sebelah hilirnya. Pada posisi kelokan sungai disisi luar erosi lateral terjadi dengan arah yang berlawanan dengan arah erosi lateral sisi tebing sungai sebelumnya di bagian hulu.

Terjadinya proses pembentukan meander yang disebabkan adanya erosi lateral pada dinding lembah lengkung luar (outer band), maka disisi lainnya yaitu pada lengkung dalam terjadi arus yang lebih lemah daripada tali arus yang kuat di lengkung luar, sehingga pengendapan sedimen pada lengkung dalam (inner band) secara intensif terjadi membentuk gosong titik (point bar). Demikian seterusnya pengikisan/erosi lateral berlangsung dalam jangka waktu yang lama, dan sungai berkelok (sonousity) menjadi semakin besar, dan yang akhirnya membentuk kelokan sangat besar (meander). Dengan demikian sungai meander adalah sungai yang berkelok-kelok, yang wilayah perkembangannya berada pada kemiringan dasar sungai (gradien) yang kecil (Charton, 2000; Lowrie, 2007). Pada meander tersebut terjadi dua penomena spesifik yaitu bagian dasar sungai yang lebih dangkal dari sekitarnya (riffle) yang pada umumnya terdapat pada bagian alur lengkung dalam (inner band), dan kedua adalah bagian dasar sungai yang lebih dalam /ledokan yang lebih dalam (pool atau pothole) yang pada umumnya terletak pada alur sungai lengkungan luar (outer band).

Sebuah gosong sungai (bars) merupakan daerah yang mengalami agradasi akibat pengendapan sedimen (seperti pasir atau kerikil) yang telah disuplai oleh aliran air. Jenis gosong sungai termasuk gosong sungai yang tersebar di dasar saluran sungai (river bottom) yang sering disebut gosong sungai teranyam (braided river bar) dan point bars yang berkembang umumnya di dalam alur sungai yang berkelok-kelok pada lengkung dalam dan gosong muara sungai yang disebut dengan delta sungai (Strahler and Strahler, 1979, 1996). Gosong sungai biasanya didapatkan pada kecepatan aliran sungai yang paling lambat, pada bagian sungai yang dangkal, sering sejajar dengan dengan garis garis tebing sungai dan menempati daerah terjauh dalam tali arus dengan aliran tercepat (thalweg). Lokasi gosong sungai ditentukan oleh geometri sungai dan aliran sungai tersebut. Gosong sungai titik (point bars) terbentuk dan berkembang menempel bagian lengkung dalam (inner band) sungai yang berkelok akibat dari aliran sungai dialur dangkal dengan 
kecepatan aliran rendah serta tegangan geser yang rendah sehingga di tempat jumlah material sedimen yang diangkut diendapkan pada tempat tersebut. Material sedimen terangkut sebagian besar mengendap pada dasar sungai lengkungan maupun dasar sungai pada umumnya sebagai gosong sungai (Charlton, Rosemary. 2008).

Alur sungai yang mengalami perlengkungan (sinous) umunya adalah alur-alur sungai berumur dewasa (maturity stages) dimulai pada zona penggal sungai tangah (middle zone) yang mempunyai gradien sungai sungai landai hingga datar. Pada stadium ini dataran banjir (flood plain) mulai berkembang. Setelah berkembangnya alur sungai menjadi melengkung (sinous), maka terjadilah kondisi morfometri aliran sungai, dimana pada alur sungai lurus, morfometri penampang sungai simetri berbentuk $\mathrm{U}$ berdinding terjal maupun berbentuk $U$ melebar, tali arus dengan kecepatan yang paling tinggi (thalweg). Pada bagian sisi lengkung dalam (inner bend), kekuatan arus mengakut sedimen lebih rendah daripada kekuatan arus sungai dibagian lengkung luar (outer bend) yang lemah. Dengan demikian pada sisi ini terjadi pengendapan sedimen di mulai dari bagian bawah dinding lembah berangsur-angsur menuju ke arah tengah alur sungai secara bertahap membentuk gosong lengkung dalam (point bars). Masing-masing endapan hasil proses sedimentasi scara periodik akibat kecepatan aliran sungai dan proses pengendapan yang berbeda-beda mempunyai kemiringan lereng permukaan endapan yang berbeda seraya maju ke arah depan dari bagian sedimen yang telah mengendap sebelumnya. Hal ini tergantung kepada ukuran massa butir sedimen pada masing-masing periode pengendapan (slip off slope) seperti ditunjukkan pada Gambar 1.

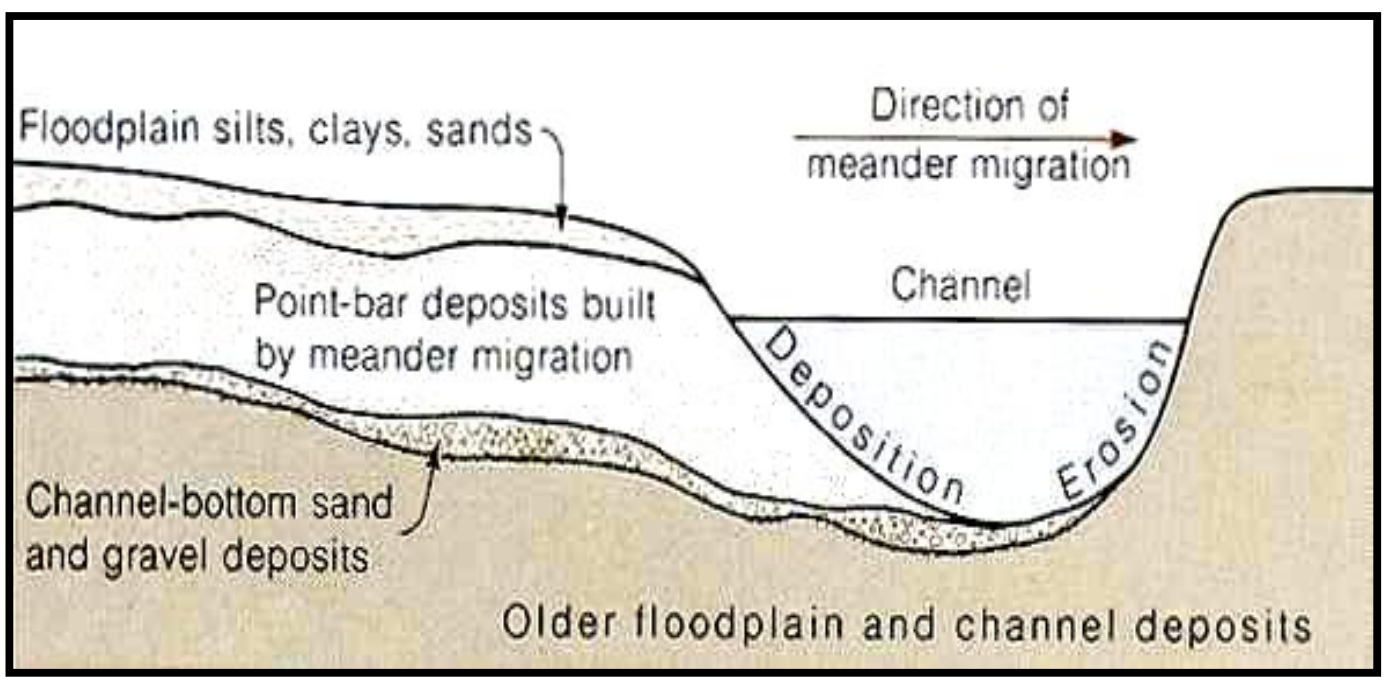

Gambar 1. Perkembangan meander dan point bars (Charlton, 2008)

Disisi lain pada saat aliran sungai besar dan mempunyai debit tinggi mampu mengangkut sedimen yang mempunyai ukuran butir yang besar (kompetensi sungai tinggi) dalam jumlah debit sedimen yang tinggi pula (kapasitas sungai tinggi). Dikarenakan adanya fluktuasi debit aliran sungai dan pada saat kecepatan aliran berkurang, maka sebagian material sedimen yang tidak mampu diangkut oleh aliran sungai akan diendapkan pada 
sepanjang dasar sungai dan memanjang searah aliran sungai. Kemudian pada waktu debit sungai meningkat, aliran air akan membawa muatan sedimen yang banyak. Akan tetapi karena gerakan aliran sungai terhambat oleh endapan dasar sungai sebelumnya, maka sebagaian sedimen akan diendapkan dalam tiga arah kesamping kiri kanan dan sebagian karena mengalir di atas endapan sedimen yang ada sebelumnya. Jadi karena adanya eddies flow aliran sungai akan mengalir di atas endapan sedimen dasar sungai sebelumnya.

Adanya fluktuasi naik dan turun kecepatan aliran serta debit aliran sungai tersebut akhirnya membentuk endapan sedimen dasar sungai yang pada umumnya berukuran pasir halus hingga kasar yang disebut sebagai gosong sungai (sand bars). Relief pada gosong sungai pada umumnya datar-berombak, struktur batuan berlapis akibat pengendapan sedimen secara serial, secara pandangan planar mempunyai bentuk memanjang dengan bidang lebar dan agak tumpul di bagian hulu gosong dan meruncing di bagian hilir (tail) gosong

Salah satu sungai di Indonesia yang mengalami dinamika sungai berupa proses pengikisan lateral badan sungai dan pengendapan berupa bars adalah penggal sungai Bogowonto pada bagian hilir. Kenampakan sungai Bogowonto dibagian hilir menunjukkan bentukan meander, point bars, dan dataran aluvial yang terlihat jelas. Gambar penggal sungai Bogowonto bagian hilir ditunjukkan pada Gambar 2.

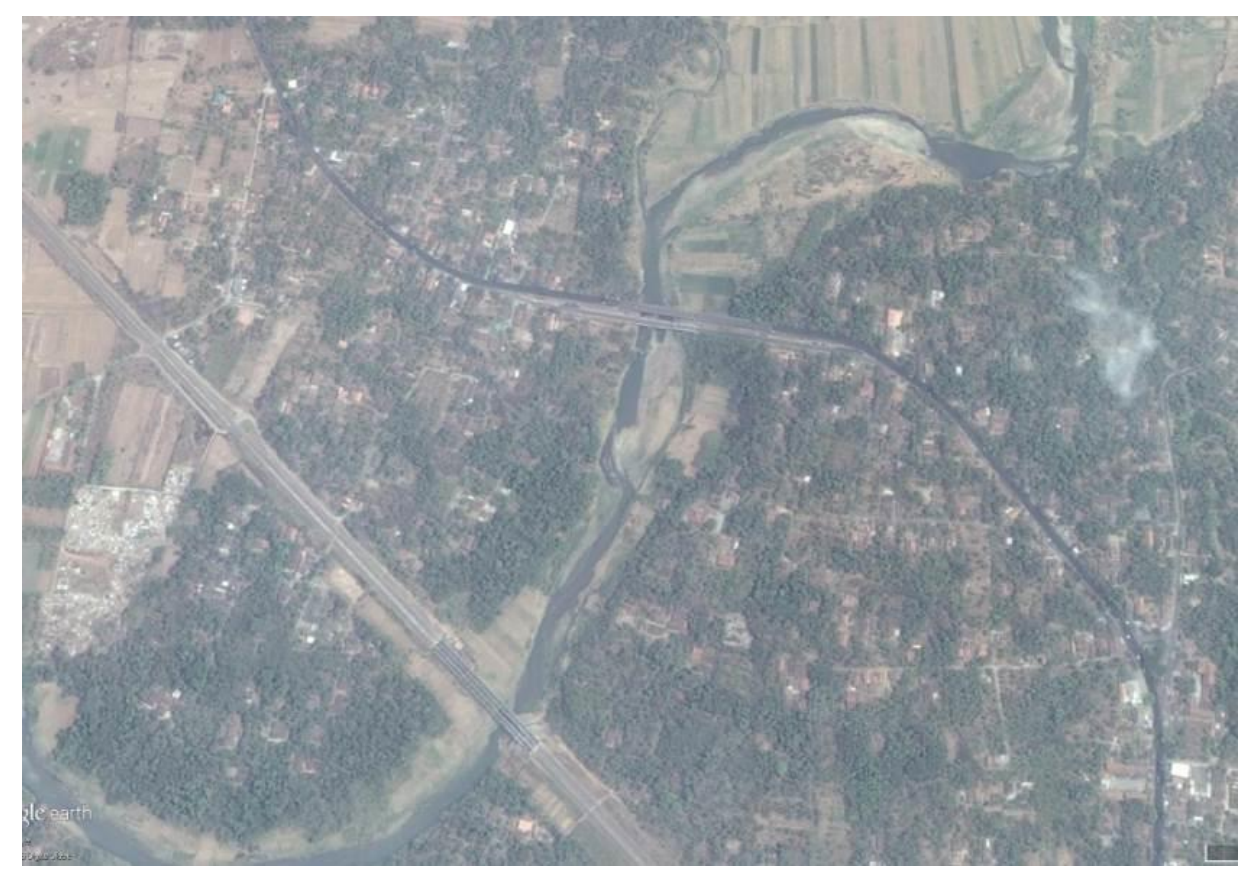

Gambar 2. Penggal Sungai Bogowonto bagian hilir

\section{METODE}

Bahan dan alat yang yang digunakan dalam penelitian adalah:

a. Bahan

1. Peta Rupa Bumi Indonesia Lembar Wates dan Purworejo skala $1: 25000$; dan

2. Citra Geoeye Tahun 2016. 
b. Alat

1. UAV (Unmanned Aerial Vehicle) untuk pengambilan foto udara skala rinci;

2. Bor tangan (Hand auger) untuk pengambilan sampel material tanah/sedimen dengan mata bor tipe tube bit;

3. Seperangkat komputer dengan spesifikasi "Intel (R) Core (TM) i5 - 3210 m CPU @2,50 $\mathrm{GHz}$ dan perangkat lunak ArcGIS 9.3.;

4. GPS untuk plotting koordinat titik sampel di lapangan;

5. Kamera untuk dokumentasi kenampakan di lapangan;

6. Plastik sampel tanah;

7. Alat tulis; dan

8. Penggaris $(30 \mathrm{~cm})$ dan pita ukur panjang ukuran 50 meter,

Penelitian ini dilakukan dengan metode survei, yaitu dengan melakukan pengamatan, pengukuran dan pencatatan langsung terhadap parameter-parameter yang terkait dengan penelitian di lapangan. Penentuan unit sampel dilakukan dengan metode purposive systematic sampling. Semua pelaksanaan penelitian dengan metode survei tersebut dikelompokkan ke dalam tiga tahapan dalam penelitian ini yang meliputi tahap persiapan (pra lapangan), tahap kerja lapangan, dan tahap pasca lapangan. Berikut dijelaskan kegiatan-kegiatan masing-masing tahapan penelitian:

1. Tahap Persiapan (Pra lapangan)

Kegiatan-Kegiatan yang dilakukan pada tahap ini meliputi:

a. Pemilihan daerah penelitian.

Daerah penelitian yang dipilih adalah penggal sungai meander Bogowonto di bagian hulir seperti yang ditunjukkan Gambar 3.

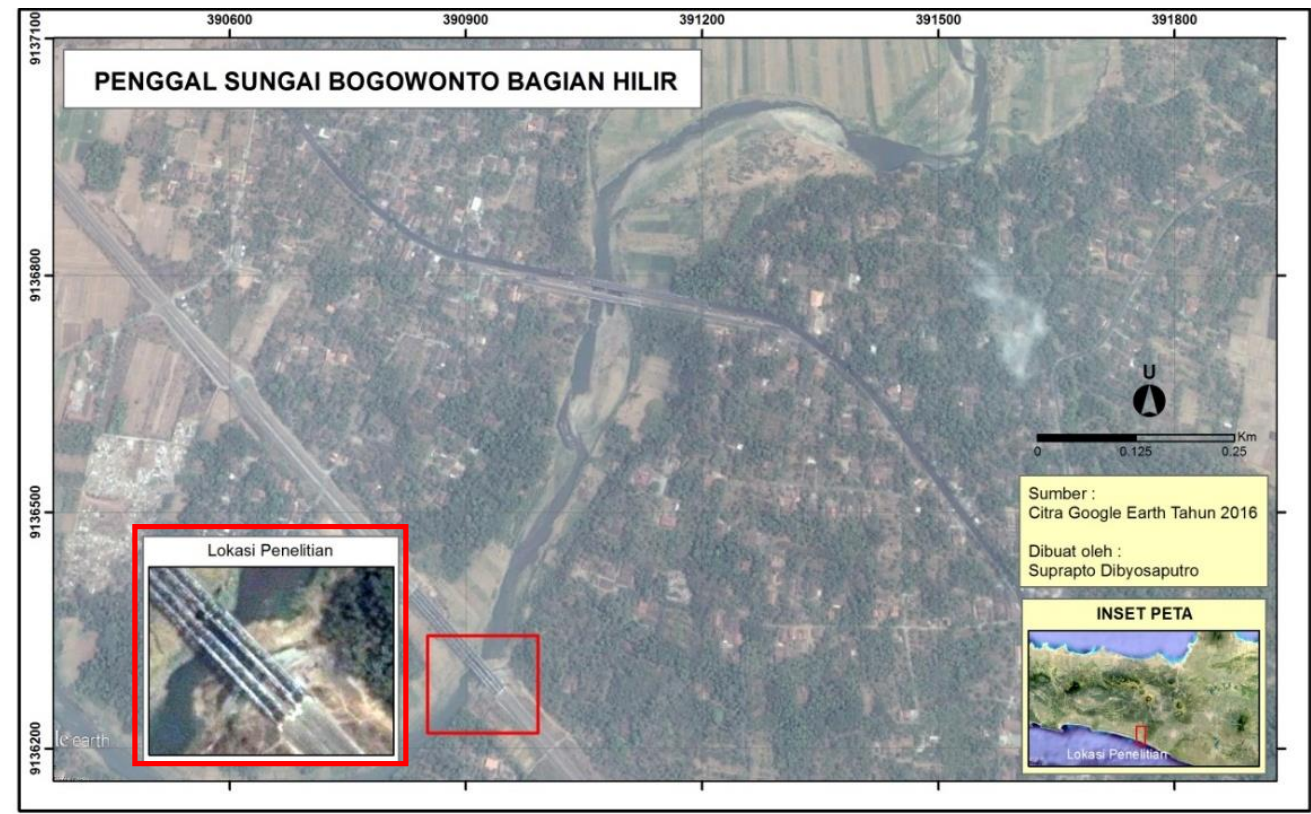

Gambar 3. Peta Lokasi Wilayah Penelitian 
b. Studi literatur, pengumpulan data sekunder, dan pengumpulan peta-peta dasar.

c. Penyiapan bahan dan alat penelitian

2. Tahap Kerja Lapangan

Tahap kerja lapangan terbagi menjadi tiga sub tahap kerja lapangan, yaitu survei pendahuluan atau orientasi lapangan, kegiatan wawancara kepada masyarakat di sekitar sungai Bogowonto terkait kerusakan yang timbul di sekitar sungai, dan survei terakhir untuk pengukuran lapangan.

a. Survei pendahuluan dan pemotretan udara menggunakan UAV

Survei pendahuluan dilakukan pada Selasa, 26 April 2016. Tujuan kegiatan lapangan ini dilakukan untuk melihat kondisi aktual di lapangan wilayah kajian. Selain itu dalam kegiatan ini dilakukan juga pengambilan foto udara menggunakan UAV (Unmanned Aerial Vehicle) guna mendapatkan gambaran kondisi aktual wilayah kajian. Foto udara yang diambil meliputi wilayah kajian point bar utama, meander sungai, dataran banjir, dan lembah sungai Bogowonto.

Pemotretan udara dapat dilakukan dengan menggunakan UAV quadcopter dari DJI serie Phantom 3 Professional. Alat tersebut cocok digunakan untuk pemotretan udara skala besar karena memliki fitur pemetaan otomatis yang dapat diatur jalur terbangnya. Hasil pemotretan udara menggunakan alat ini dapat diolah menjadi DSM (Digital Surface Model) atau DTM (Digital Terrain Model) bila dibutuhkan. Alat ini mampu terbang dengan ketinggial maksimal sampai 250 meter dengan jarak jangkauan sampai 1000 meter. Kenampakan alat ini dapat dilihat pada Gambar 4.

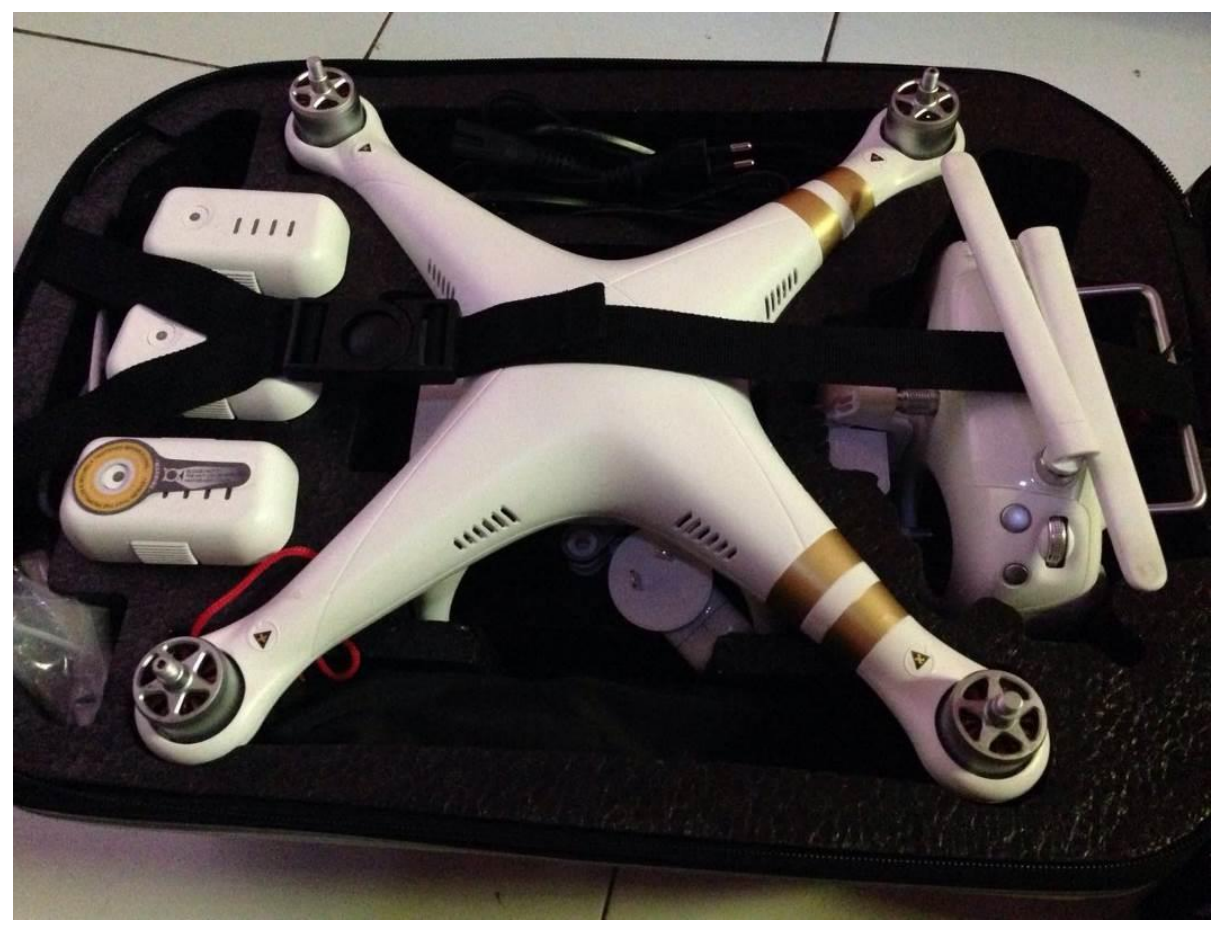

Gambar 4. UAV tipe DJI Phantom 3 Professional 
Perekaman udara menggunakan UAV tipe DJI ini tergolong tidak rumit. Lintasan terbang dapat diatur sesuai dengan kebutuhan. Jarak antar jalur akan ditentukan secara otomatis setelah pajang dan lebar area pemotretan telah ditentukan. Jarak antar jalur lintasan dipengararuhi oleh pengaturan ketinggan terbang dan overlap antar foto. Semakin tinggi terbang maka jarak jalur lintasan akan semakin lebar. Kenampakan contoh lintasan terbang UAV ditunjukkan Gambar 5.

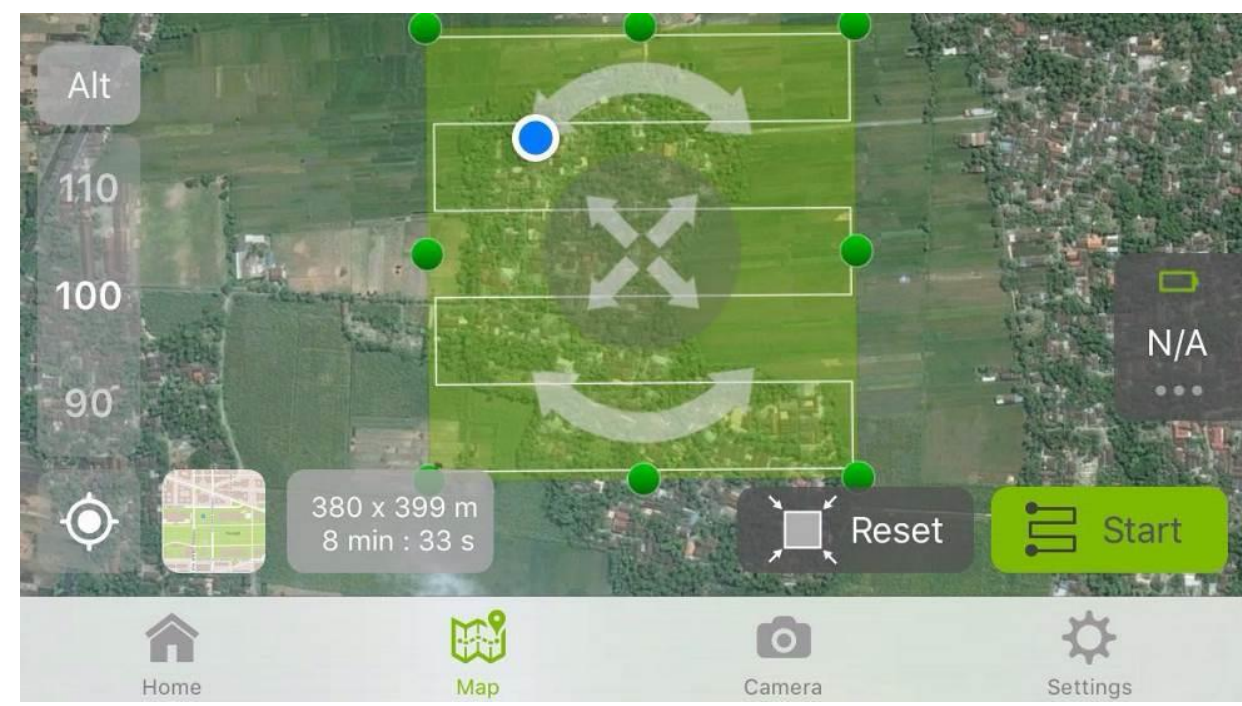

Gambar 5. Contoh kenampakan jalur lintasan perekaman UAV

Kelemahan yang dimiliki oleh alat tersebut adalah daya baterei yang lemah. Baterai tergolong cepat habis dengan waktu terbang sekitar 25 menit. Dalam rentang waktu demikian, area yang dapat dipetakan kurang lebih seluas 10 hektar dengan dua kali lintasan terbang. Hal lain yang perlu diperhatikan adalah saat akan berpindah jalur lintasan. Pemindahan jalur tersebut harus memperhatikan jalur sebelumnya agar hasil foto tetap bertampalan sehingga tidak ada blank area.

Hasil pemotretan selanjutnya diolah menjadi foto udara yang ter-georeferensi dengan bantuan software AgiSoft. Software tersebut digunakan untuk menggabungkan foto-foto hasil pemotretan (mozaik) dan melakukan georeferensi terhadap hasil mozaik foto. Untuk menjadi sebuha foto udara dengan referensi geografis yang baik, maka diperlukan pengukuran GCP (Ground Control Point) sebagai titik ikat koordinat $x, y, z$ dari area yang dipetakan. GCP tersebut dapat dilakukan pada saat pemotretan dilakukan atau setelah foto selesai dimozaik.

b. Pengukuran lapangan

Kegiatan pengambilan sampel dilakukan pada Minggu, 7 Agustus 2016. Tujuan kegiatan lapangan ini dilakukan untuk mengidentifikasi stratigrafi dan ukuran butir sedimen penyusun point bar. Pengambilan sampel sedimen dilakukan dengan Systematic Random Sampling pada jalur tengah point bar. Pengambilan sampel sedimen dilakukan menggunakan bor tanah dengan mata bor tipe tabung (tube), karena sedimen yang diambil merupakan sedimen lepaas berukuran pasir halus 
hingga krakal. Pengeboran sampel sedimen dilakukan secara vertikal dengan kedalaman tertentu.

Hasil sampel sedimen selanjutnya diidentifikasi secara manual meliputi kenampakan warna, variasi ukuran butir, tebal setiap lapisan, dan kenampakan lain yang bisa diamati secara langsung. Selanjutnya sampel sedimen dimasukkan kedalam plastik untuk dipersiapkan uji laboratorium terhadap analisis ukuran butir (grain size analysis).

3. Tahap Pasca Lapangan

Tahap pasca lapangan yang dilakukan adalah pengoalahan dan analisis data. Kegiatan pengolahan data yang dilakukan adalah sebagai berikut :

a. Analisis laboratorium ukuran butir sedimen

b. Penggambaran peta bentuklahan point bar skala detil, grafik-grafik

c. Deskripsi karakteristik point bar (morfologi dan morfometri)

d. Kerusakan lingkungan daerah pada dan sekitar akibat dinamika point bar.

\section{HASIL DAN PEMBAHASAN}

\section{Point bar di Sungai Bogowonto}

Point bar merupakan salah satu bagian dari bentanglahan sungai. Salah satu bentukan ini termasuk dalam satu bentuklahan dengan alluvial floodplain. Point bar merupakan salah satu bentuklahan yang sering mengalami perubahan (Chong, 2001). Contoh perubahan yang dapat diambil adalah salah satunya terletak di penggal Sungai Bogowonto pada bagian hilir. Berikut adalah gambar salah satu point bar yang diambil pada Citra GeoEye tahun 2015 yang ditunjukkan oleh Gambar 6.

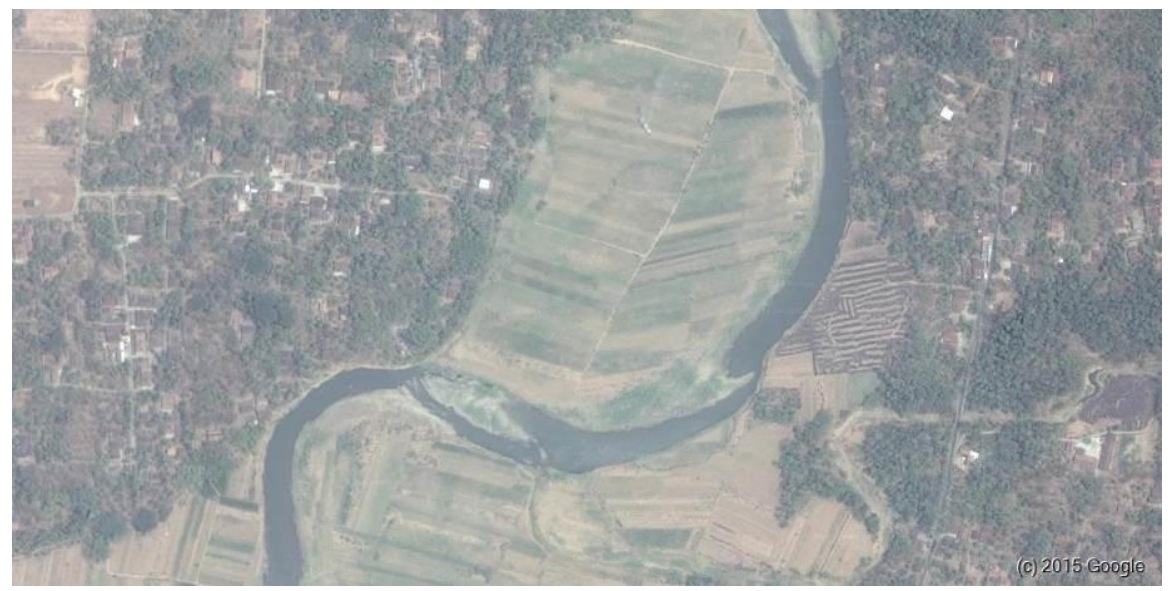

Gambar 6. Point bar pada penggal Sungai Bogowonto bagian hilir

Gambar 6 menunjukkan bahwa bentuk dari dataran banjir (alluvial floodplain) yang dibatasi oleh dan terletak sekitar alur sungai berbentuk setengah lingkaran (half-curve), serta point bar yang menyatu dengan alluvial floodplain sebagaian tanahnya sudah mulai berkembang. Hal ini ditunjukkan oleh adanya banyak vegetasi yang tumbuh baik tumbuhan alami maaupun budidaya pada dataran banjir dan point bar tersebut. Citra tahun 2015 ini 
juga menunjukkan bagaimana alur sungai yang masih melengkung membentuk yang masih berkembang, sedangkan alluvial floodplain yang belum terkikis oleh aliran sungai Bogowonto tersebut. Setelah satu tahun berikutnya, perubahan point bar telah berkembang dan berubah bentuknya disertai dengan pengikisan pada alluvial floodplain. Perubahan point bar dan alluvial floodplain pada tahun 2016 ditunjukkan oleh Gambar 7.

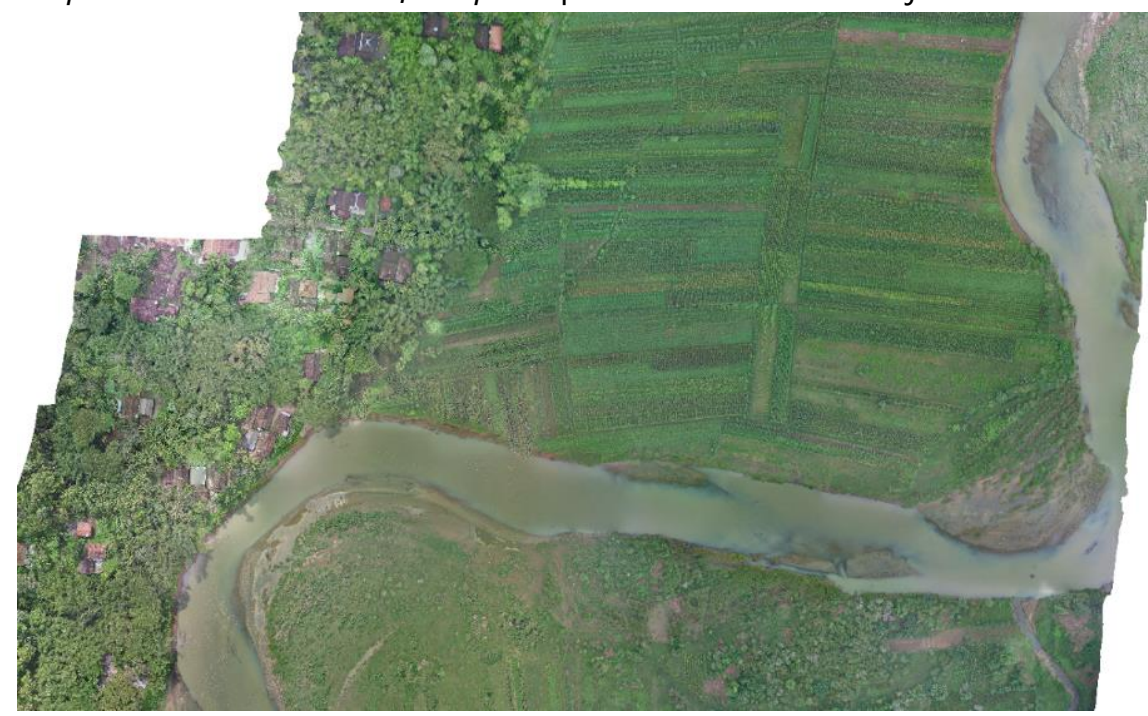

Gambar 7. Perubahan point bar dan alluvial floodplain tahun 2016

Perubahan bentuk point bar serta alluvial floodplain pada tahun 2016 cukup besar. Bentuk point bar yang terpengaruhi oleh proses geomorfologi yang terjadi di wilayah sekitar sungai berupa banjir. Bentuk point bar yang semula menyatu dengan alluvial floodplain dalam bentuk setengah lingkaran pada tahun 2015, telah berubah menjadi bentuk setengah lingkaran tersendiri dan materialnya berupa pasiran dan kerikil.

Adanya perkembangan point bar di penggal sungai Bogowonto bagian akhir juga disertai perubahan morfometri dan morfologi dari point bar itu sendiri. Bentuk dan ukuran morfometri pada point bar tersebut ditunjukkan pada Tabel 1. Selain perubahan morfologi dan morfometri, arah dan bentuk aliran sungai juga ikut berubah mengikuti bentuk dari point bar itu sendiri. Bentuk dan arah aliran sungai cenderung berubah arah dinding tanggul depan akibat adanya point bar yang menghalangi arus aliran sungai tersebut.

Tabel 1. Morfometri Point Bar

\begin{tabular}{|c|c|}
\hline Variabel Pengukuran & Nilai \\
\hline Panjang & $138,36 \mathrm{~m}$ \\
\hline Lebar & $87,4 \mathrm{~m}$ \\
\hline Keliling & $217,335 \mathrm{~m}$ \\
\hline Luas & $7.512,63 \mathrm{~m}^{2}$ \\
\hline Panjang Kelengkungan & $220,21 \mathrm{~m}$ \\
\hline Sinusitas & 1,59 \\
\hline Kedalaman 1 & $133 \mathrm{~cm}$ \\
\hline Kedalaman 2 & $255 \mathrm{~cm}$ \\
\hline
\end{tabular}

Sumber: pengukuran di lapangan 
Karena terjadi perubahan morfometri, maka proses yang terjadi berikutnya akan disertai dengan adanya perubahan morfologi berupa lapisan point bar yang terletak di bagian slip-off slope serta perlapisan sedimen secara senada. Gambar 8 menunjukkan penggambaran morfologi point bar yang berupa igir dan lembah di bagian slip-off slope.

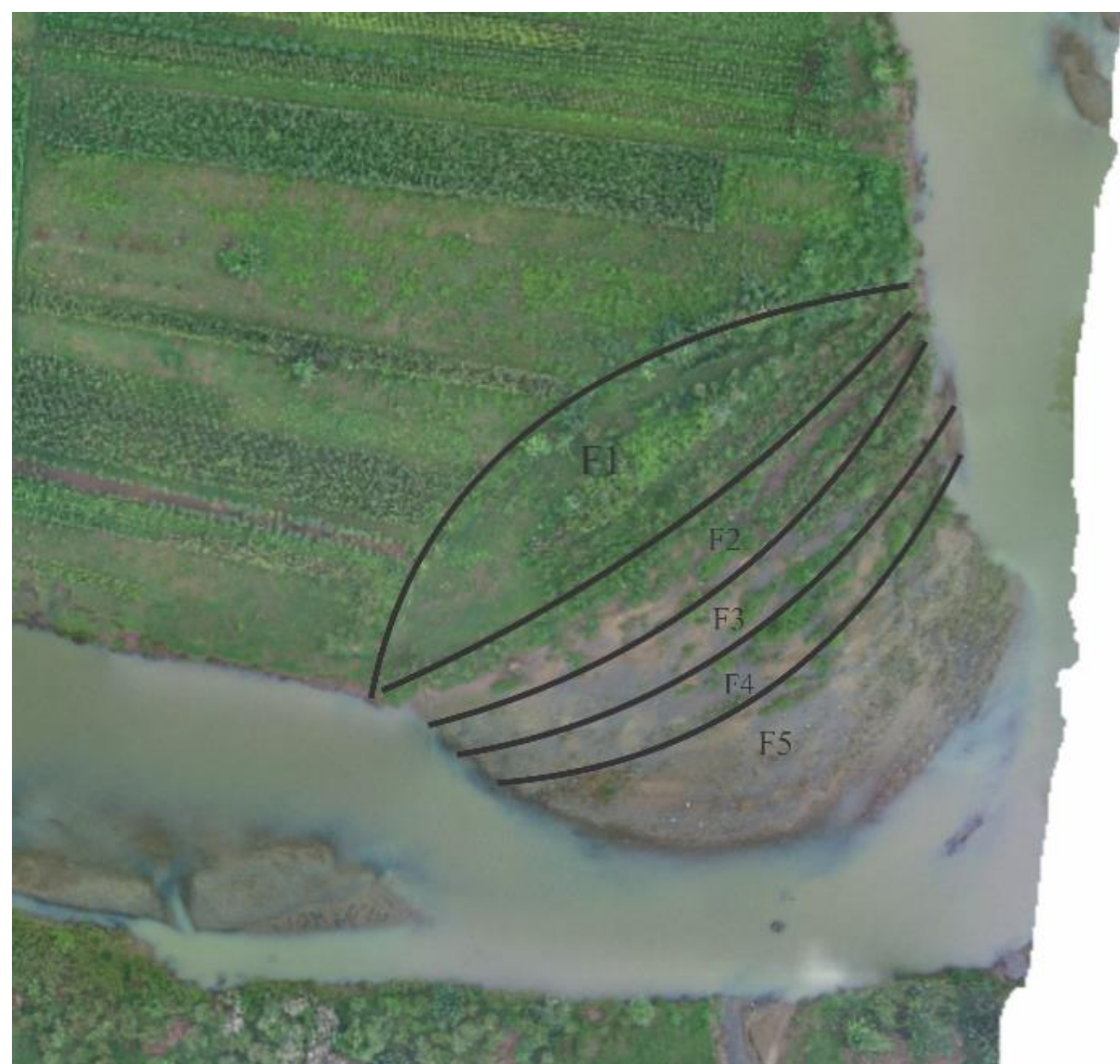

Gambar 8. Perkembangan maju (slip off slope) point bar dengan igir dan lembah pada point bar

Morfologi slip-off slope igir dan lembah di area point bar, digambarkan pada dalam gambar garis dengan urutan angka pada Kode $\mathrm{F}$ bagian terluar yaitu kode F5 adalah endapan sungai baru yang terbentuki akibat adanya proses geomorfologi yang selalau merubah bentuk point bar tersebut. Endapan baru (recent) ini memiliki material berukuran pasir kasar, kerikil dan kerakal. Area F5 ini belum mengalami campur tangan manussia (antrhopogenic) dan masih murni belum ditumbuhi oleh tanaman semak atau rumput ilalang. Bagian F5 ini memiliki kemiringan lereng yang cenderung datar (3\%) dan dekat serta berdampingan laangsung dengan aliran sungai. Area F5 dibatasi igir (ridge) yang berada di bagian dalam badan point bar dan ditunjukkan dengan adanya tumbuhan di bagian salah satu sisi igir tersebut. Kode F4 merupakan bagian lembah (swale) yang dibatasi 
kembali oleh igir yang digambarkan oleh garis hitam tebal. Area pada morfologi dengan kode F4 ini merupakan endapan sungai yang suda lebih lama dan terjadi sebelum adanya endapan baru pada kode F5. F4 memiliki karakteristik yang hampir sama dengan F3 dan F2. Selain dibatasi oleh igir dan adanya tumbuhan pada bagian igir tersebut, bagian permukaan dari F2, F3 dan F4 tersusun ataas material berupa pasir halus dan pasir sedang dengan batas yang tidak tegas akibat adanya perubahan morfologi point bar. Namun demikian, karakteristik pada morfologi F1 berbeda dengan kode sebelumnya. F1 yang berkembang diposisi paling belakang point bar telah ditumbuhi vegetasi dan beberapa telah terpengaruhi oleh kegiatanmanusia dengan tanaman budidaya berupa kacang tanah dan jagung. Endapan pada F1 merupakan endapan sedimen sungai tertua dalam dalam susuan pengemdaapan yang telah berkembang menjadi tanah dan terdapat material berupa lempung, debu dan pasir secara gradual pada permukaannya. Hal itu ditunjukkan dengan adanya vegetasi yang tumbuh subur pada area ini. Apabila bentukan pada F1 ini masih berupa pasir halus atau pasir sedang, maka belum dapat dimanfaatkan untuk ditanami tanaman budidaya seperti pada perkembangan endapan di area F5, F4, F3, dan F2.

\section{SIMPULAN}

Berdasarkan hasil pembahasan dalam penelitian ini, dapat ditarik beberapa kesimpulan bahwa point bar selalu berkembang sejalan dengan berkembangnya sungai menjadi meander, di mana point bar berkembang pada lengkung dalam (inner band) dan erosi lateral (cut bank) dan vertikal pada lengkung luar (outer band); dan morfologi point bar sebagai hasil dari serial endapan sedimen sungai secara bertahap pada lengkung dalam sungai berkembang menjadi bertambah luas ke arah maju (slip-off slope) dengan membentuk igir (ridges) dan ledok memanjang (swale) secaara berurutan.

\section{UCAPAN TERIMA KASIH}

Dengan telah selesainya penyusunan laporan penelitian dan dilanjutkan penyusunan naskah publikasi jurnal ini, penulis menyampaikan ucapan terima kasih sebesar-besarnya kepada Saudara-saudara Ahmad Cahyadi, M.Sc., Zulhan Effendy, S.Si, Haviz S.Si., Muhammad Ngainul, Andhoko, Irvan, yang telah dengan sepenuhnya membantu penulis dalam pengumpulan sampel butir sedimen di lapangan. Selanjutnya juga bantuan yang sangat besar dalam analisia di laboratorium untuk pengukuran morfometri butir sedimen (panjang, lebar dan tebal) serta pengukuran jari-jari lingkaran batu material sedimen. Sekali lagi atas bantuan saudara-suadara, penulis menyampaikan banyak terimakasih

\section{DAFTAR PUSTAKA}

Charlton, R. 2008. Fundamental of Fluvial Geomorphology. New York : Routledge

Constantine, JA., Dunne, T., Ahmed, J., Legleiter, C., and Lazarus, ED. (2014). Sediment supply as a driver of river meandering and floodplain evolution in the Amazon Basin. UC Santa Barbara Previously Published Works, Nature Geoscience, 7(12)

Chong, M. 2001. Aspects of Physical Geography, Singapore: Pekoe Books 
Hickin, E.J. 2003. Meandering Channels., in Middleton, Gerard V. 2003. Encyclopedia of Sediments and Sedimentary Rocks. New York: Springer, p. 432 ISBN 1-4020-0872-4

Hooke, J.M. 2003. Coarse Sediment Connectivity in River Channel System : A Conceptual framework and Methodology. Geomorphology, 56 : 79-94

Huang, J., Greimann, B.P., dan Randle, TJ. 2013. Modelling of meander migration in an incised channel. Elsevier. International Journal of Sediment Research, 29: 441-453.

Hudson, P.F., Heitmuller, F.T., dan Leitch, M.B. 2012. Hydrologic connectivity of oxbow lakes along the lower Guadalupe River, Texas: The influence of geomorphic and climatic controls on the "flood pulse concept. Journal of Hydrology: 414-415.

Labrecque, A.L., Jansen, J.L., Hubbard, S.S., dan Nielsen, H. 2011. Sedimentology and Statigraphy Architecture of poin bar deposit, Lower Crateceous McMurray Formation, Alberta Canada. Bulletin of Canadian Petrolium Geology, 59: 147-171.

Leopold, L. B., dan M. G. Wolman. 1957. River channel patterns: braided, meandering, and straight. U.S Geological Survey Prof. Paper 282-B.

Leopold, L. B., M. G. Wolman dan J.P. Miller. 1964. Fluvial process in geomorphology. San Francisco: Freeman. 522 pp.

Lola, D.P., Constantine, J.A.. Hales, T.C.., Piégay, H., dan Riquier, J. 2013. The role of oxbow lakes in the off-channel storage of bed material along the Ain River, France. Elsevier. Geomorphology: 188.

Lowrie, W. 2007. Fundamentals of Geophysics, 2nd Edition. Cambridge: Cambridge University Press.

Martha, T.R, Sharma, dan Kumar, K.V. 2015. Development of meander cutoffs-a multitemporal satellite-based observation in parts of Sindh River, Madhya Pradesh, India. Arab Journal of Geoscience 8: 5663-5668.

Rodríguez-Zorro, P.A., Enters, E., Hermanowski B., Lima, da Costa M. dan Behling, H. 2015. Vegetation changes and human impact inferred from an oxbow lake in Southwestern Amazonia, Brazil since the 19th century. Journal of South American Earth Sciences 62:186-194.

Strahler, A.N., dan A.H. Strahler. 1979. Modern Physical Geography. New York: John Willey $\&$ Sons Inc.

Strahler, A, dan Strahler, A. 1996. Introducing Physical Geography. New York: John Wiley \& Sons Inc.

Willem H. J., Toonen, Maarten G,. Kleinhan, dan Kim, M.C. 2011. Sedimentary architecture of abandoned channel fills. Earth Surface Processes and Landforms 37: 459-472.

Zinger, J.A., Bruce L., Rhoads, James L. Best, dan Kevin J. K. 2013. Flow structure and channel morphodynamics of meander bend chute cutoffs: A case study of the Wabash River, USA. Journal of Geophysical Research, 118: 2468-2487. 